\title{
IFITM1 Gene
}

National Cancer Institute

\section{Source}

National Cancer Institute. IFITM1 Gene. NCI Thesaurus. Code C24480.

This gene is involved in the regulation of cell growth and proliferation. It also plays a role in immunity/defense. 